\title{
A SCYTHIAN AGE SUNKEN CIRCULAR STRUCTURE IN THE VICINITY OF HAJDÚBÖSZÖRMÉNY (HUNGARY)
}

\author{
Marianna Bálint - Alexandra Scard - Robert G. Scholtz
}

DOI: https://doi.org/10.31577/szausav.2019.suppl.1.1

Keywords: Carpathian Basin, Middle Iron Age, Scythian Age, Vekerzug culture, settlement, semi-subterranean circular structure, yurt, bronze arrowhead, clay spindle whorl, ceramics

\section{A Scythian Age sunken circular structure in the vicinity of Hajdúböszörmény (Hungary)}

The Hajdúsági Museum of Hajdúböszörmény conducted a research excavation in Hajdúböszörmény, Juhász-szállás, where a Scythian Age settlement was found in 2017. The primary purpose of this paper is to represent a sunken circular settlement structure of the Vekerzug culture and its relative problems. The authors distinguished three main structure types: those without any post-holes (type-A), those with one post-hole in the center (type-B) and those with multiple post-holes (type-C). The origin, direction and time of their geographical distribution requires further research.

\section{INTRODUCTION}

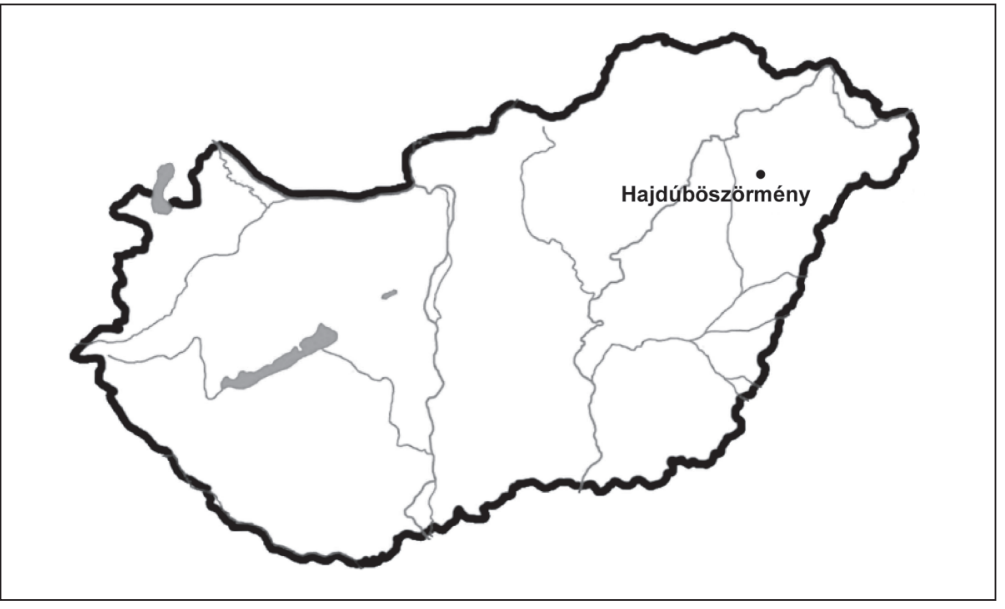

Fig. 1. Hajdúböszörmény in Hungary.
The Great Hungarian Plain (the so called Puszta/Alföld) has very rich Scythian Age assemblages (Chochorowski 1985; Kemenczei 2009; Párducz 1973). ${ }^{1}$ Since the last decade of the $19^{\text {th }}$ century at least 200 burial places and more than 3000 graves had been disturbed by different earthworks, yet only in a few cases were settlements mentioned (e.g. Tiszavasvári, Dózsa-telep - Lengyel $1960,20) .^{2}$ As a result of this, in the middle of the 1980's archaeologists knew almost nothing of the settlements of the Scythian Age population of the Alföld (Chochorowski 1985, 130-133).

For decades, researchers explained this phenomenon with the nomadic lifestyle of the people, based primarily on the preserved written documents. As the contemporary Ionian historian Herodotus writes: "... for they who have neither cities founded nor walls built, but all carry their houses with them and are mounted archers, living not by the plough but by cattle, and whose dwellings are upon cars, these assuredly are invincible and impossible to approach" (Herodotus, 4.46).

1 This culture is known as the Scythian Age Alföld/Vekerzug group, or Vekerzug Culture in scholarly literature. Its research was largely based on finds unearthed from cemeteries, hoards and sporadic finds, while settlements have been hardly known until now (Kemenczei 2009; Scholtz 2010b).

2 Based on the recent data of the archeodatabase of the Hungarian National Museum, 802 Scythian Age sites - 183 cemeteries, 61 burials, 212 settlements - are known in Hungary (https://archeodatabase.hnm.hu). This data should be handled cautiously as the system has several failures - incorrect chronological data of the sites - and deficiences. Furthermore, the sites of other counties are still being processed. 


\section{SCYTHIAN AGE SETTLEMENTS}

Due to the preventive excavations and extensive field walking surveys of the last three decades, settlements dating to the period were brought to light one after the other (Cseh 2006; Czifra 2006; Kemenczei 2009; Scholtz 2007b; Veres 2007). The new finds, not only help archaeologists to describe the inner structure of individual settlements, but also provide an opportunity to reconstruct the regional settlement structure, as well as the house building techniques of the Vekerzug Culture (e.g. Almássy 2001; Cseh 1990; Gyucha 2001; Istvánovits 1997; Németi 1999; Scholtz 2001; 2010b; Veres 2007). Communities of the Vekerzug Culture lived in flat, hamlet-like settlements built along watercourses, on high terraces above the floodplain. ${ }^{3}$ These settlements generally consist of adventitiously built semi-subterranean structures, outdoor ovens, pits, ditches and wells. ${ }^{4}$ In most cases there is little sign of detailed settlement planning on these partly excavated sites (Czifra 2016; 2019, 246; Lantos 2011). Unfortunately, at present no fully excavated Scythian Age settlement has been known in the Carpathian Basin.

\section{Semi-subterranean structures}

The semi-subterranean structures of the Vekerzug Culture are generally characterised as singleroomed features of rectangular shape, with rounded corners, vertical or slightly inclining walls, elevated (or uneven) base and two or more postholes. ${ }^{5}$ Their size ranges between $10-18 \mathrm{~m}^{2}$ and fireplaces or ovens are not common features within these structures. ${ }^{6}$ Beside these general structures, sunken circular features have been recovered on more than 20 sites (Table 1; Pl. V). Based on the evidence from these collective sites, we have found that these structures can be found on the whole territory of the Vekerzug Culture. Research suggests that the highest concentration of such features can be detected in the surroundings of Nitra and Szolnok (Miroššayová 2018, fig. 4; Romsauer 1998).7

Archaeologists interpret these circular structures as yurt-like houses, sheilings, or round-houses (Rundhütte, e.g. Elisavetovskoje house 5 - Marchenko/Zhitnikov/Yakovenko 1988; Czifra 2016; 2019; Sinical Tel'nov 2014). ${ }^{8}$ It is the opinion of Andrea Vaday that the circular structures from Salgótarján, Industry Park II, could have been workshops, economic buildings, storage or working pits (Vaday 2003, 33). Unfortunately, a typology of these settlement features with particular regard to shape, depth and size has not yet been created at this stage (Cattani 1994, 213). The primary purpose of this paper is to present a newly unearthed Scythian Age sunken circular structure from the vicinity of Hajdúböszörmény county Hajdú-Bihar, Hungary.

\section{HAJDÚBÖSZÖRMÉNY, JUHÁSZ-SZÁLLÁS, PARTOS-CSÁRDA}

The Hajdúsági Museum of Hajdúböszörmény conducted a research excavation during the summer of 2017, to determine the exact extent and condition of the Hajdúböszörmény, Juhász-szállás, also known as Partos-csárda archaeological site (Fig. 1; Pl. I). The focus of the project was to gain as much data as possible on the previously known archaeological site, where a vast Roman-style amphora came to light

3 The elevation of the Scythian Age archaeological sites of our county (Hajdú-Bihar) ranges between 109-111 m above the Baltic Sea level.

4 Beside the semi-subterranean houses above ground constructions with plastered floors were reported from Tiszalök, Prison (Scholtz 2007b, 54), and Salgótarján, Industry Park II (Vaday 2003, 33).

5 At present, two reconstructions are known of such Vekerzug buildings (Szolnok, Zagyvapart - Cseh 1990, fig. 5 and Nyíregyháza, Manda-bokor - Istvánovits 1997, fig. 69).

6 The remnants of fixed dome ovens or hearths were unearthed in some circular residential buildings, while the presence of burned traces on the floors of other dwellings may suggest the use of portable heating installations, such as braziers (Kashuba/Levitski 2012, 573).

7 One could hypothesise that their sporadic occurence could be explained by the lack of research or recovery in certain areas.

8 Currently, very little is known about Scythian yurts. A well-known wall-painting from the Anthesterius grave in Kerch shows how the yurts of Scythian times might have looked (Rolle 1989, fig. 88). Similarly, the internal detail of a contemporary yurt - Kidin-Hutrans yurt, c. 600 BC - can be seen on the bronze bowl from Arjan (Iran). David Stronach suggests that these type of yurts could have been brought to Iran at the time as the Persians first entered the region, around the beginning of the first millennium BC (Stronach 2004, 11, fig. 3; 4). 
in the middle of the 1960s (Nepper/Máté 1972).9 The site is located north of Hajdúböszörmény, east of Hajdúvid, on the right bank of the Vidi-ér (Vidi-stream; Pl. I: 1). Traces of the settlement were found on a small sand hill on the western shore of the one-time waterlogged floodplain, Partos-rét. The elevation ranges between 109-111 m above the Baltic Sea level. During the investigation, 12 archaeological features - eight beehive shaped pits, two postholes, a house and one ditch - were uncovered on an area of 660 $\mathrm{m}^{2}$ (Pl. I: 2, 3). Due to the lack of datable artefacts only three features $-6-8-$ can be securely dated to the Middle Iron Age. The small size of the excavation area further limits the data regarding the structure of the settlement.

Table 1. Scythian Age sunken circular structures in Hungary.

\begin{tabular}{|c|c|c|c|c|}
\hline & Site & Other & Type & Literature \\
\hline 1. & Bükkaranyos & more than 1 & $B$ & unpublished \\
\hline 2. & Döge & 2 & B & unpublished \\
\hline 3. & Dunavecse & more than 10 & $A, B, C$ & Lantos 2011 \\
\hline 4. & Ebes, Zsong-völgy & more than 1 & $B$ & Dani 2004 unpublished \\
\hline 5. & Ecser & more than 1 & $B$ & unpublished \\
\hline 6. & Endrőd 19, feature 37 & 1 & $B$ & Cattani 1994 \\
\hline 7. & Hajdúböszörmény, Juhász-tanya, feature 6 & 1 & $\mathrm{~B}$ & Bálint/Scholtz/Scard \\
\hline 8. & Hajdúböszörmény & 1 & B & unpublished \\
\hline 9. & Hajdúnánás, feature 8 & 1 & B & unpublished \\
\hline 10. & Halmaj & more than 10 & $A, B, C$ & unpublished \\
\hline 11. & Jászfelsőszentgyörgy, Túróczi-tanya & $1(?)$ & B & Cseh 2006 \\
\hline 12. & Ludas, Varjú-dülö & more than 1 & $\mathrm{~B}$ & Domboróczki 2004 \\
\hline 13. & Nagykálló, Industry Park, feature 734 & more than 1 & B & Scholtz 2010a \\
\hline 14. & Nyírparasznya & more than 1 & $A, B, C$ & Czifra et al. 2017 \\
\hline 15. & Salgótarján, Industry Park II & more than 6 & $A, B, C$ & Vaday 2001 \\
\hline 16. & Szikszó, Hell & more than 1 & A, B & unpublished \\
\hline 17. & Szolnok, Besenyszög & $1(?)$ & B & unpublished \\
\hline 18. & Szolnok, Papp-tanya & $1(?)$ & B & unpublished \\
\hline 19. & Szolnok, Zagyvapart (Alcsi) & $1(?)$ & B & Cseh 1999 \\
\hline 20. & Tiszalök, Prison & more than 1 & $A, B$ & Scholtz 2007a \\
\hline 21. & Tiszapüspöki, Karancs-Háromág-dűlő, feature 140 & 2 & B & Csányi/Cseh/Tárnoki 1999 \\
\hline 22. & Törökszentmiklós, Kenderpart, feature 22 & 3 & B & Cseh 2001a \\
\hline 23. & Vecsés, site 4, feature 96 & 2 & B & unpublished \\
\hline 24. & Vecsés, site 67 & 3 & B & Rácz 2004 \\
\hline
\end{tabular}

Features

\section{Feature 6}

An oblong-shaped, semi-subterranean house (?) covering an area of $284 \times 342 \mathrm{~cm}$ (Pl. II). Its discolouration appeared rather faintly in the sandy ground, with the different moisture retention abilities of the feature being the only indication of an archaeological phenomenon. The walls of the structure were slightly arched, its plastered floor uneven. The greatest depth from the excavated surface was $18-20 \mathrm{~cm}$. A posthole was uncovered in the center of the feature, with a diameter of $28 \mathrm{~cm}$ and depth of $45 \mathrm{~cm}$. The whole feature was filled in with a black humus mixed with small daub fragments. On the north-western side of the structure, an oval feature with a plastered base was uncovered: probable the entrance of the structure (Pl. II: 3).

Find assemblages: hand-made and wheel-thrown ceramics (Pl. III; IV), bronze arrowhead (Pl. IV: 9), clay spindle whorl (Pl. IV: 7), animal bones (including dog) and daub fragments.

\section{Feature 8}

The oval shape of the posthole appeared rather ambiguously on the sandy surface, $2.3 \mathrm{~m}$ eastward from feature 6 . No artefacts were recovered from the fill of the feature, which had slightly inclining sides and a round base. It measured $43 \mathrm{~cm}$ in diameter and $26 \mathrm{~cm}$ deep from the excavated surface (Pl. II: 4).

\footnotetext{
9 The site has historical connections with the adjacent site Hajdúvid, Lenin utca 5. (present day Áron Gábor street), where a vast Roman-style amphora was recovered. The archaeological investigation was undertaken between July $7^{\text {th }}$ and August $2^{\text {nd }}$ 2017, under the leadership of Marianna Bálint. The artefacts can be found in the Hajdúsági Museum, Hajdúböszörmény. The vast Roman-style amphora is still unpublished.
} 


\section{Feature 9}

The oval shape of the posthole appeared rather ambiguously on the sandy surface, $1.5 \mathrm{~m}$ eastward from feature 6 . No artefacts were recovered from the fill of the feature, which had slightly inclining sides and a round base. It measured $45 \mathrm{~cm}$ in diameter and $26 \mathrm{~cm}$ deep from the excavated surface. The almost identical design of the two postholes, alongside the close proximity of $1.9 \mathrm{~m}$ between the two, indicates that they were part of the same structure.

\section{Discussion}

Though the number of Scythian Age burials discovered in Hungary to date is close to three thousand and their coverage is at a satisfactory level, it is difficult to summarise the results of the research on settlement during this era. The publication of the settlements - despite preliminary archaeological reports and presentations of prominent settlement phenomenons - is still pending in most cases. This is especially true in Hajdú-Bihar county, where aside from the announcement of Scythian burials and sporadic artefacts (Fodor 2011; 2013; 2015; Hága/Németi 2015; Kemenczei 2009; Nepper 1968), publications dealing with the settlements of the era have scarcely appeared (Berettyóújfalu, Nagy-Bócs-dúló - Dani et al. 2006; Ebes, Zsong-völgy - Dani 2004, Polgár, Csőszhalom-dűlő - Raczky 2004; Polgár, Homok-dűlő - Veres 2003).

\section{The archaeological material and chronological distribution of the site}

The materials of the Hajdúböszörmény, Juhász-szállás site, show a combination of cultures (Pl. III; IV). Alongside the characteristic objects of the surviving Late Bronze Age Gáva population, the presence of elements of the Scythian culture suggest that the composition of the Vekerzug Culture was certainly not straightforward.

\section{Hand-made ceramics}

The excavation yielded numerous artefact assemblages, none of which were overly colourful. Almost one hundred percent of the excavated material consists of hand-made and wheel-thrown pottery. Typology was made more difficult by their fragmentation, with no intact pots or complete pot profiles recovered from any of the features. Nonetheless, the sherds represent all four major vessel types of the Vekerzug Culture: large, double-cone-shaped vessels, high-handled cups (Pl. III: 2, 4, 5), bowls with inverted rims (Pl. III: 1, 12) and barrel-shaped pots (Pl. III: 3, 6, 7, 10, 11). Some of the latter were ornamented with two or three horizontal raised or indented markings, with finger impressions (Pl. III: 3 , $7,10) \cdot{ }^{10}$ Chamotte temper was characteristically used. The extensive collection of pottery types shows characteristics of the preceding periods in the Carpathian Basin, their best analogies known from the Nyírség and Northern-Alföld region (Scholtz 2008, 193; 2012).

\section{Ember covers/stainers}

Integral elements of Scythian kitchenware are the round, ember covers and stainers. A fragment of, mostly truncated, cone or hemispherical-shaped ceramic densely pierced with small holes was found in Hajdúböszörmény (Pl. III: 9). This distinctive pottery appeared first in the Late Bronze Age, though it is more often found in the assemblages of the Vekerzug Culture (Patay/Scholtz/Scard 2017, 470), as well as in the finds of the Celtic groups living together with, side-by-side or even outliving the Scythians (Sajópetri). Finding out their true function requires further research.

\section{Lids}

In Scythian settlements - sometimes in funerals - we encounter an increasing number of flat, discshaped, hand-moulded clay objects of different sizes (Pl. III: 8). They are seemingly multifunctional and could be used as lids or coversant baking sheets. Their material is coarse and tempered using chamotte, with colours varying between reddish-yellow, reddish-brown and greyish-brown. The wall of the clay covers is usually 0.9 to $2.2 \mathrm{~cm}$ thick. Similar disc covers can be found in the Scythian-Hallstatt mixed materials in both the Scythian Age Kushtanovice group and Celtic archaeological material (Czifra et al. 2017; Kemenczei 2009).

\footnotetext{
10 Though there are vessel fragments that can be evaluated archaeologically, several rim and body fragments hold information only in the form of decoration and shape.
} 


\section{Wheel-thrown ceramics}

Amongst the vessels finely levigated, wheel-thrown items were also recorded (Pl. IV: 1-6, 8, 10). Research agrees that this new pottery production technique - one of the leading inventions of prehistory - was spread in the eastern part of the Carpathian Basin by the communities of the Vekerzug Culture (Czifra/Kreiter/Pánczél 2015; Kemenczei 2001,34), though, to date, no pottery kiln has been recovered (Scholtz 2010b). Analogies of the main pottery types can often be found in the material of both grave goods and settlements within the whole territory of the Vekerzug Culture. The earliest wheel-thrown potteries appeared at the end of the $7^{\text {th }}$ century BC, belonging to the well datable Alsótelekes cemetery (Patay/Kiss 2001-2002), and existed until the end of the culture in the middle of the $4^{\text {th }}$ century BC (Kemenczei 2009).

\section{Clay spindle whorl}

The numerous, usually ornamented spindle whorls are evidence of spinning and weaving (Pl. IV: 7). The majority of the spindle whorls recovered are coarsely-made, and are fairly uniform in size (Bottyán $1955,53)$. We find them both in settlement features as well as in graves, both male and female. The spindle whorl recovered from our site has a dark grey, hand-made, biconical, undecorated form and represents the most common type of the Vekerzug Culture (Chochorowski 1985).

\section{Bronze arrowhead}

The bronze, three-winged arrowhead recovered (Pl. IV: 9) is of the type long-used throughout the whole Scythian Period (Vasiliev A2c-d type - Vasiliev 1980, 74). It appeared in the Carpathian Basin in the $2^{\text {nd }}$ half of the $7^{\text {th }}$ century BC (burial 208, Csanytelek, Újhalastó - Kemenczei 1994, 93, 98) and was in use during the whole $6^{\text {th }}-5^{\text {th }}$ centuries BC (Hellmuth 2010; Kemenczei 1994; Kozubová 2009; Tóth Farkas 2018).

\section{Typology and functions}

Of the more than 20 Scythian Age sites excavated thus far, at least 40 circular semi-subterranean structures have been unearthed in Hungary (Table 1; Pl. VI): some without any postholes (type-A: Pl. VI: 1, 2), some with one posthole in the center (type-B: Pl. VI: 3, 4), and some with multiple postholes (type-C: Pl. VI: 5, 6). They can be found throughout the majority of the territory of the Vekerzug Culture, both in its homeland and their adjacent regions, in Slovakia (Dvory nad Žitavou: Paulík 1957; Stránska: Miroššayová 2018, fig. 4; Rusnák 2007) and in Romania (Németi 1999). These structures are characterised by round or oval ground-plans, vertical or inclining sides and slightly uneven bases. Postholes are mainly discovered central to the structure (Hajdúböszörmény, Halmaj) or around the perimeter of the ground structures (Dunavecse, Nyírparasznya). Rarely has any inner fireplace or hearth being observed in these sunken features. ${ }^{11}$ Although the interpretation of such rounded settlement features is highly complex, it is very probable that some of them reflect on the, so far unknown, aspects of domestic architecture of the Vekerzug Culture (Czifra 2019). In the Carpathian Basin semi-subterranean circular constructions first appeared in Late Bronze Age - Urnfield-, Gáva-, Kyjatice-Culture - and Early Iron Age - Basarabi-, Mező́csát-Culture - settlements (Ha A-Ha C periods). ${ }^{12}$ Hungarian researchers generally interpreted these structures as ancillary constructions (Domboróczki 2004; Hellebrandt 2015; Kemenczei 2009; Lantos 2011; Szabó 2004; Vaday 2003), whilst, on the contrary, similar circular features are often interpreted as houses by eastern European archaeologists (Kashuba/Levitski 2012). ${ }^{13}$ Finally, one must be keep in mind that similar constructions can be found in large numbers in Celtic settlements in the Great Hungarian Alföld (Czifra 2019).

To date, numerous investigators have dealt with the geographical distribution and cultural-chronological context of the above mentioned features (Czifra 2019; Kemenczei 2009; Miroššayová 2018; Romsauer

\footnotetext{
11 According to ethnographic data, people did not light fires in small tents to prevent them from igniting. This may explain why archaeologists cannot find any traces of fires in buildings smaller than $2.5-3 \mathrm{~m}$ in diameter.

12 As well as rectangular, above ground medium and large-sized houses of the local Late Bronze Age cultures, rounded, semi-subterranean structures are also unearthed on many sites. These rounded features vary in size and contain additional features and can most probably be interpreted as economic buildings (Matuz 1997).

13 The analysis of the Hallstatt period house-building techniques between Carpathians and Danube showed that the tradition of building circular pit-houses has been introduced in the North-West Pontic as early as in the Ha A period, from the milieu of Hallstatt ("Carpathian-Danubian") population. In the Early Scythian period, with the direct participation and under the influence of the communities of Basarabi cultural complex, the circular pit-houses appeared here among the local forest-steppe communities (Kashuba/Levitski 2012).
} 
1998). Recently, their occurrence in stage Ha B-Ha C has been monitored in a wide zone south and east of the Carpathian Mountains, through the forest-steppe territory to the Dnieper's right bank. Their origin is sought in the Carpathian-supra-Danubian territory in stage Ha A, whence they spread eastwards (Kashuba/Levitski 2012, 574, 576; Miroššayová 1998).

Based on the analysed data, it is correct to say that the different types of circular structures - type A-C - were found near the rectangular houses of the settled, Late Bronze Age-Iron Age farming population in the Carpathian Basin. The Early and Middle Iron Age livestock keepers who arrived from the northern coast of the Black Sea also used them beside or instead of the yurt, i.e. as a permanent or periodic residential building; as a dwelling for poor people; an occasional tent or a building for summer grazing. Some of them may have been used for storage, whilst other parts in which spindle whorls and additional small postholes were found could be defined as economic structures, such as a looming house (Halmaj, Sátoralja újhely). ${ }^{14}$ The recently published Siberian rock carvings enable us to create a picture of contemporary settlements and major residential and economic buildings (Kubarev/Ceveendorzh/Jacobson 2005). Though the distance between the Hungarian and Inner Asian Scythian Age sites exceeds thousands of kilometers, we must use the comparative data to gain further understanding of these former buildings, until such a time we find a similar visual source in our area. ${ }^{15}$

14 Further, more detailed research is needed to determine the origin and function of the building types (Pl. V-VII).

15 The authors owe their thanks to I. Bacskai, Sz. Czifra, E. Miroššayová, D. Topal, M. Tóth Farkas and V. Sinica for their generous help in the publication of this paper. Drawings were made by M. Bálint, P. Szőke and E. Kövér. Photos were taken by M. Bálint, T. Horváth and I. Bacskai. The plates were made by R. G. Scholtz. 
A SCYTHIAN AGE SUNKEN CIRCULAR STRUCTURE IN THE VICINITY OF HAJDÚBÖSZÖRMÉNY (HUNGARY)

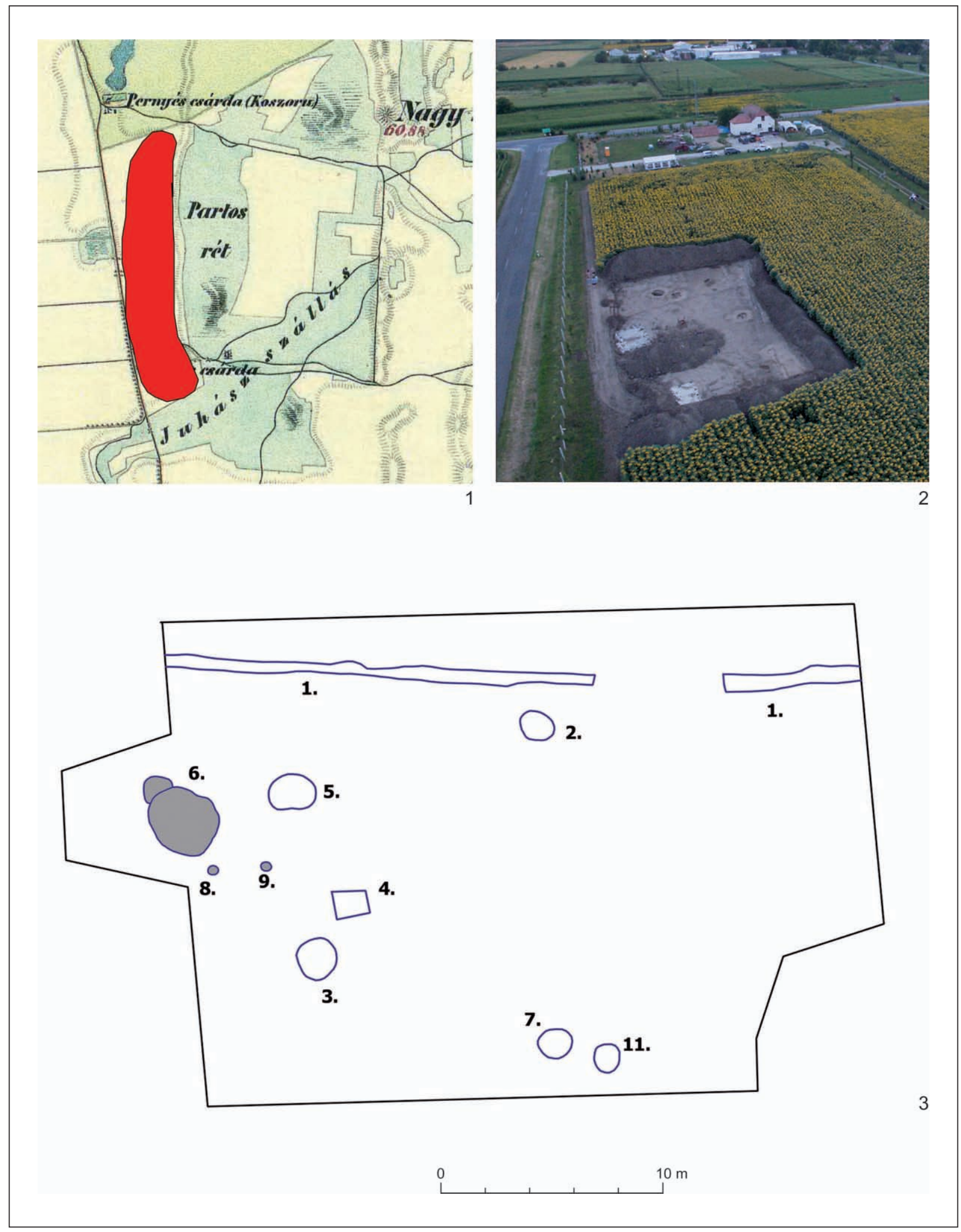

Pl. I. Hajdúböszörmény, Juhász-szállás, geographical location on the $2^{\text {nd }}$ military survey (1853) and complex map of the excavation. 

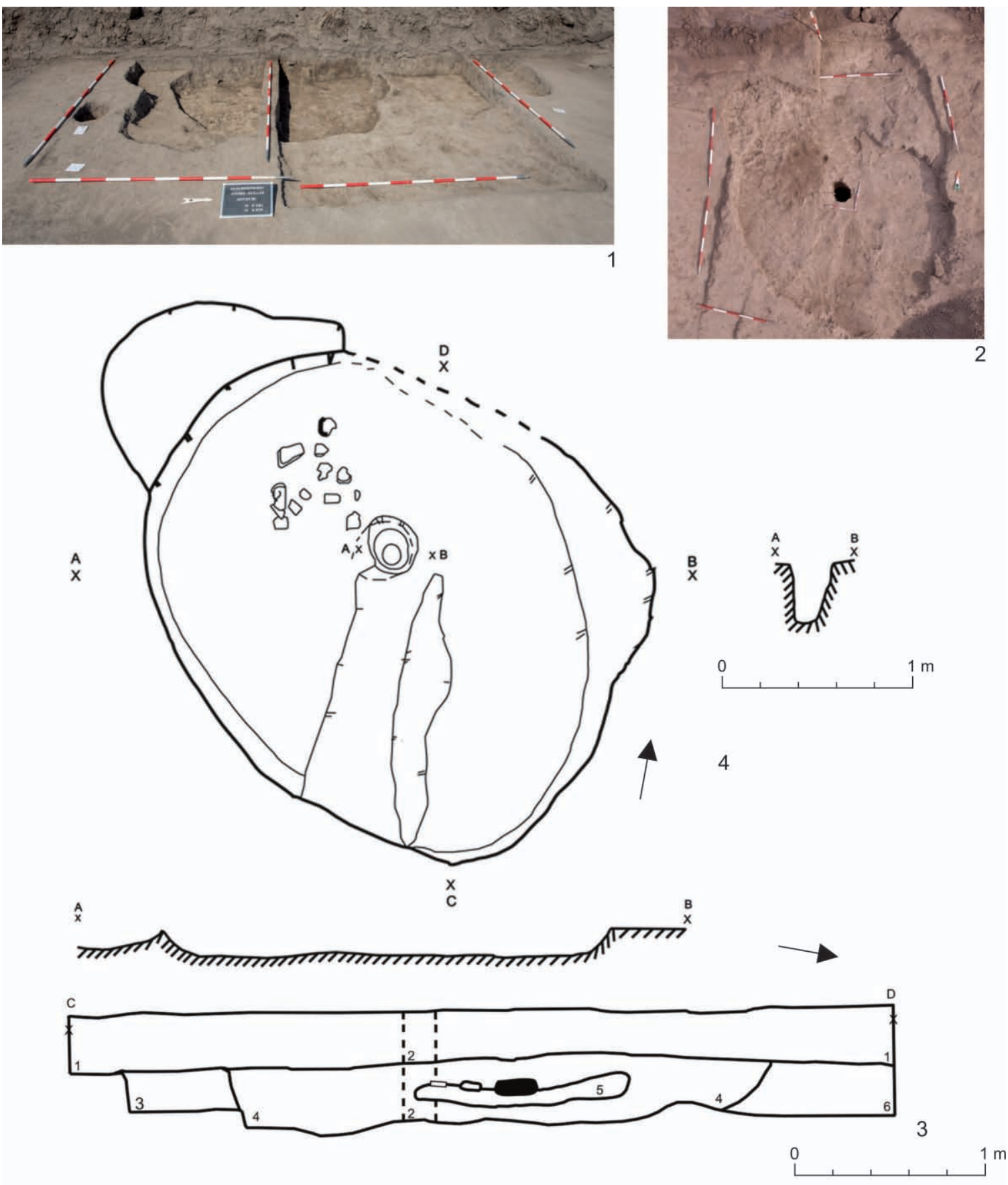

1.: Ploughed humus

2.: Section wall

3.: Light grey

4.: Light grey layer with daub fragments
5.: Reddish-brown ashy layer

6.: Yellowish-brown

$\square$ : Ceramics

: Daub 
A SCYTHIAN AGE SUNKEN CIRCULAR STRUCTURE IN THE VICINITY OF HAJDÚBÖSZÖRMÉNY (HUNGARY)

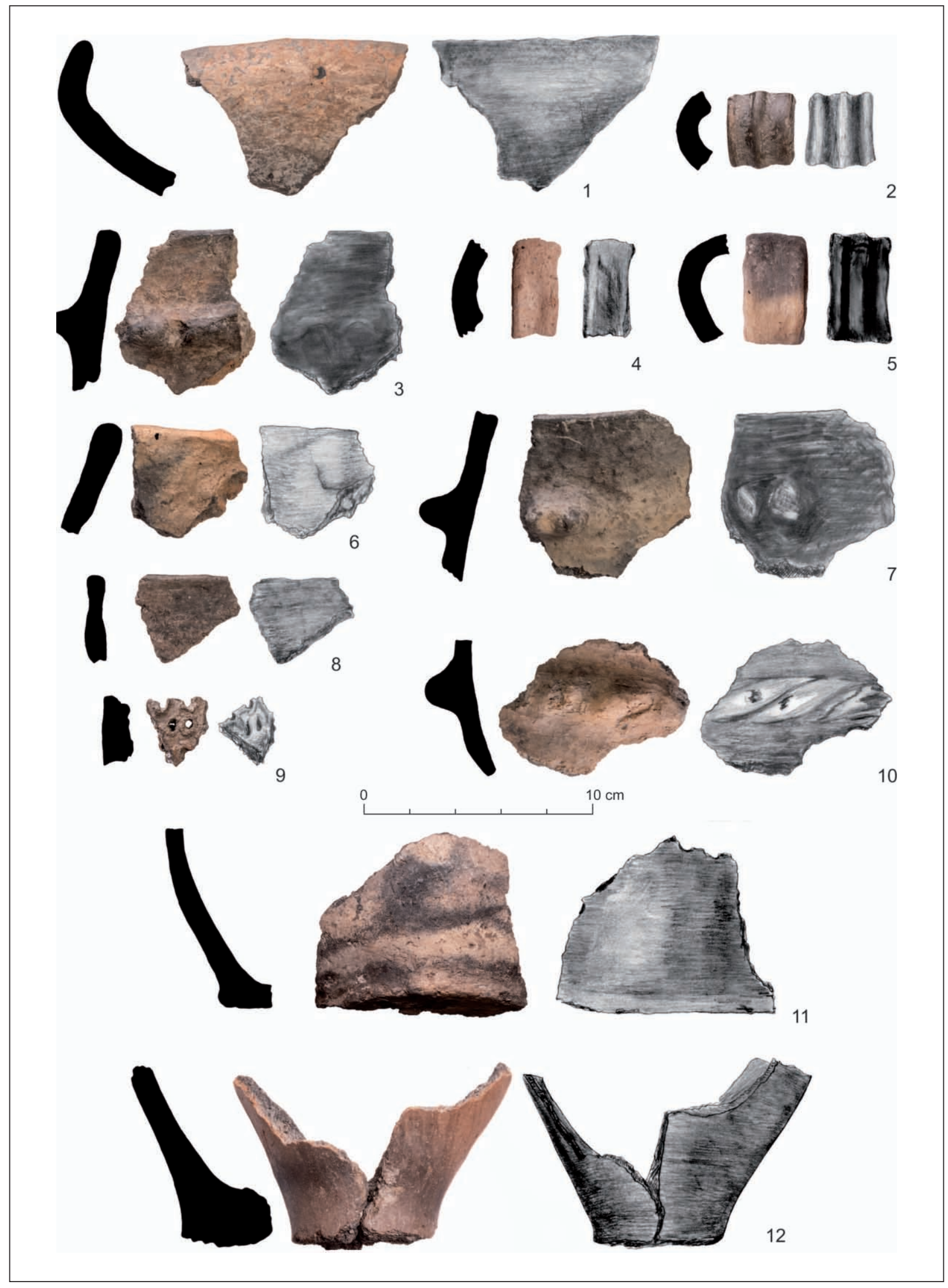

Pl. III. Selection of the archaeological finds from feature 6. Hand-made pottery. 

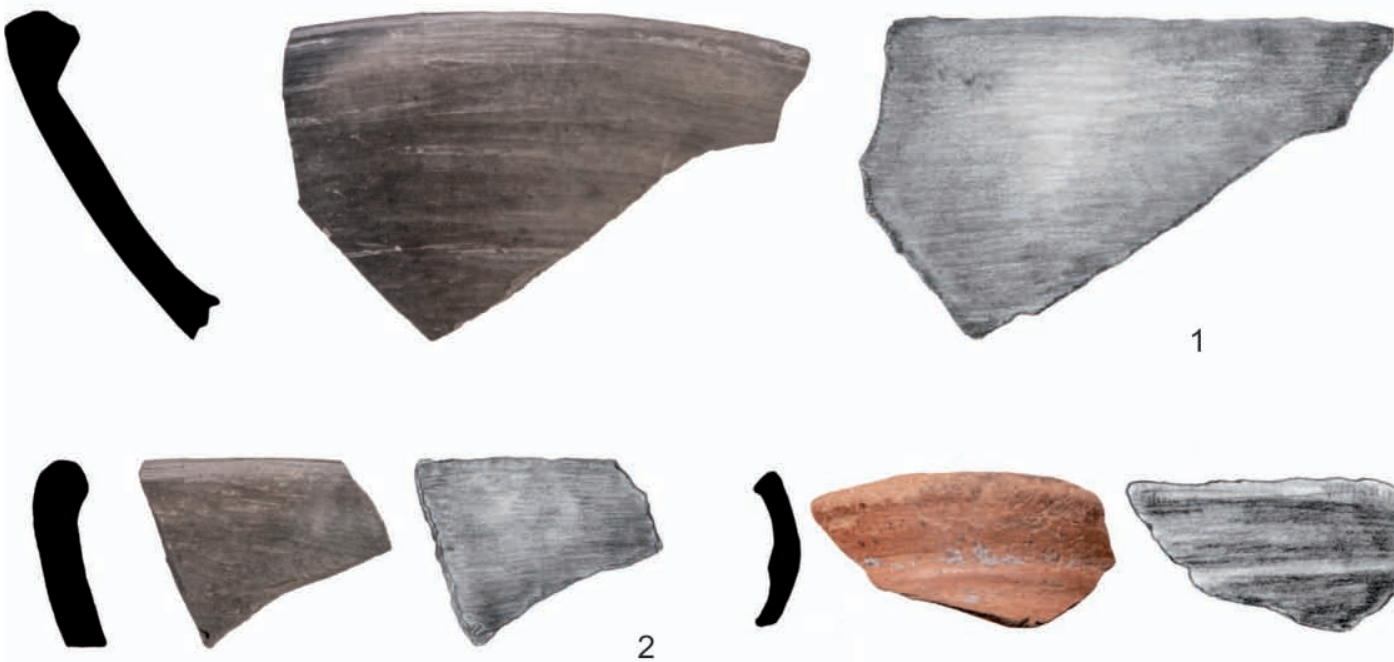

2
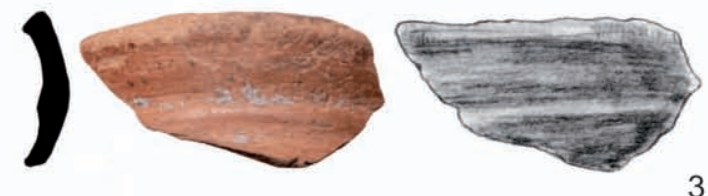

3
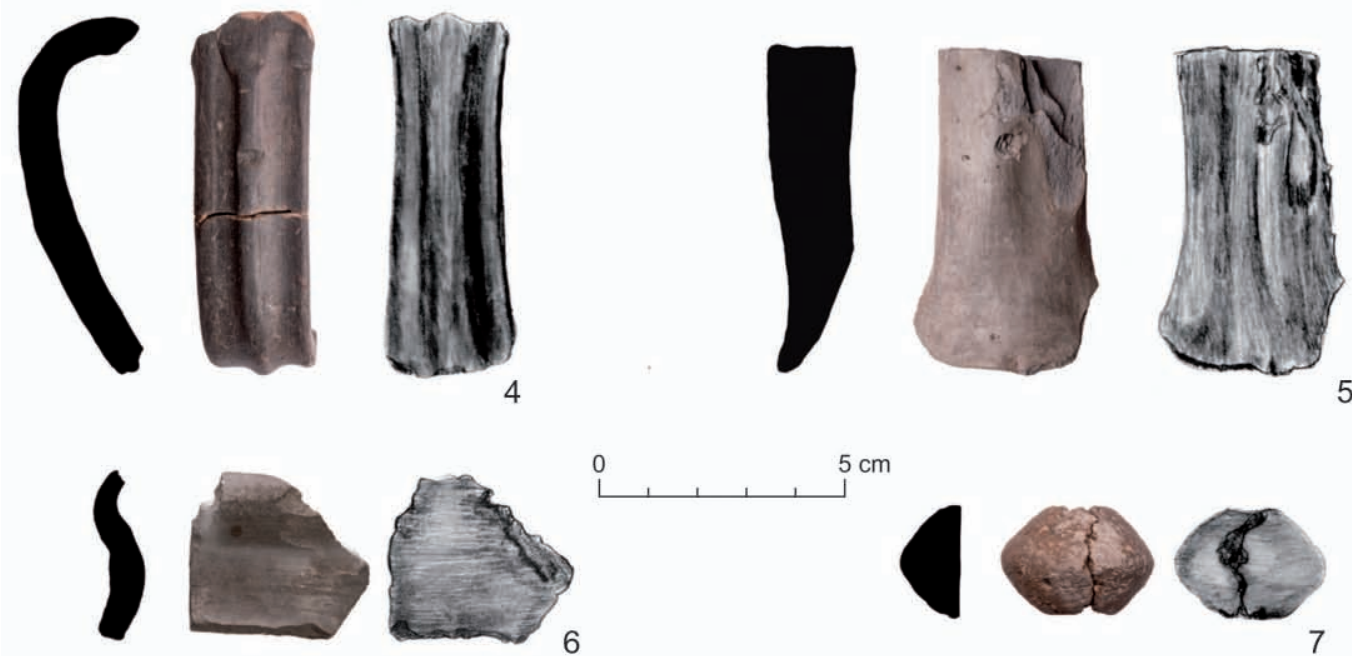

$5 \mathrm{~cm}$
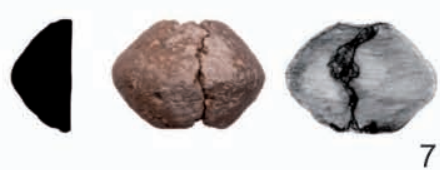
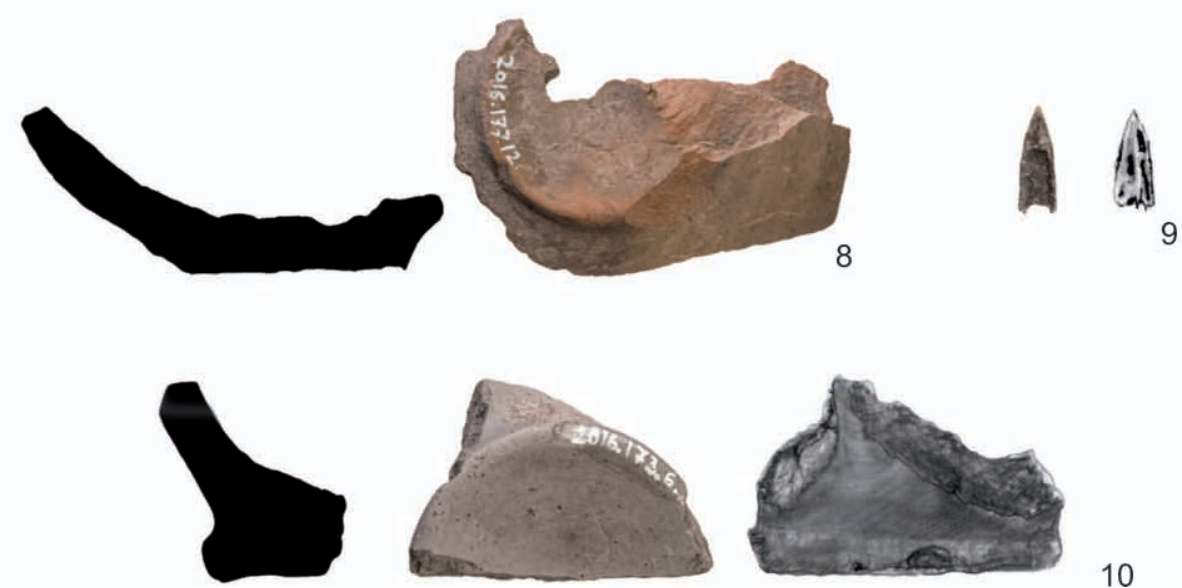

10

Pl. IV. Selection of the archaeological finds from feature 6. 1-6, 8, 10 - wheel-turned pottery; 7 - clay spindle whorl; 9 bronze arrowhead. 


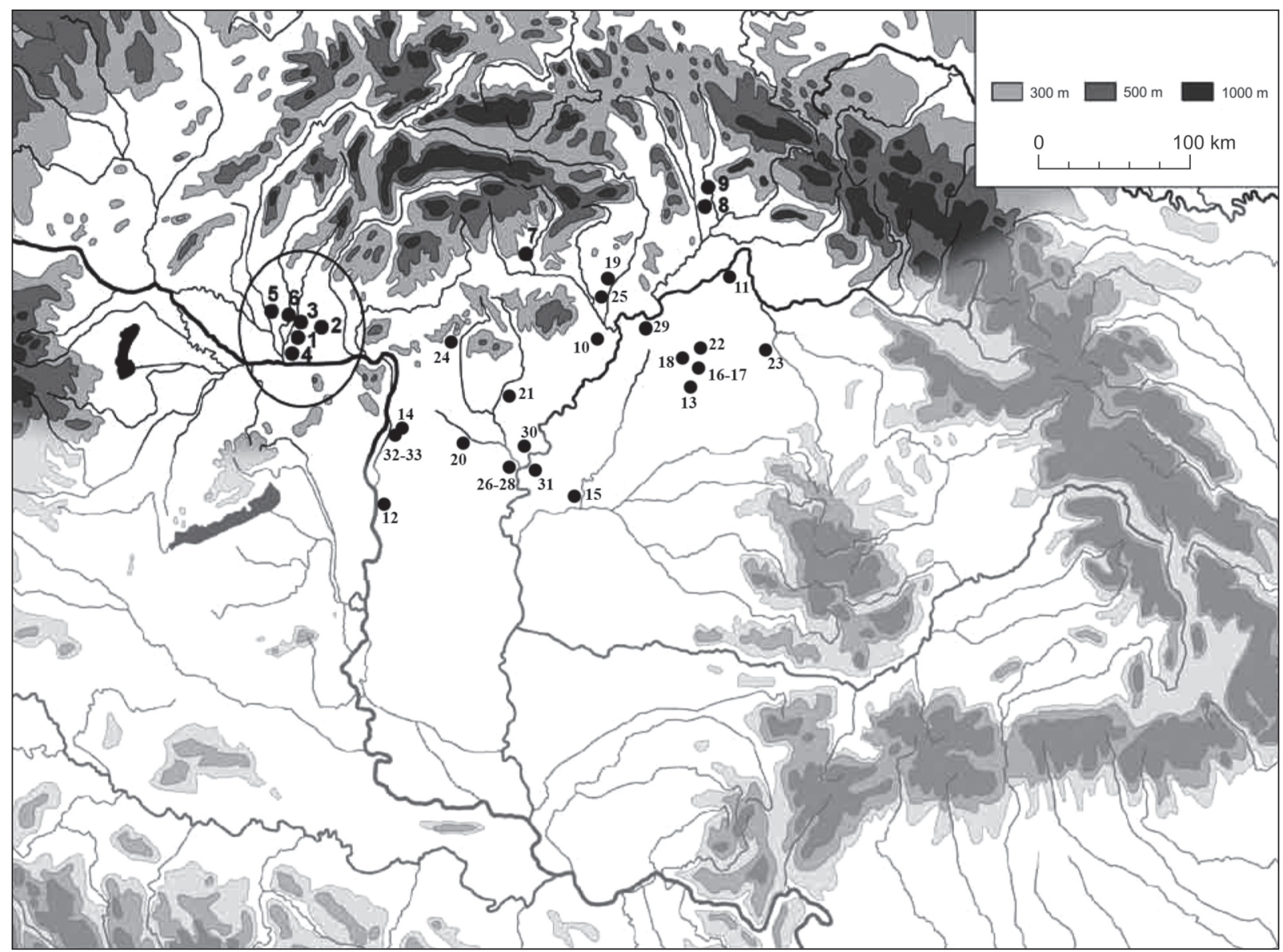

Pl. V. Map of sites with Scythian Age sunken circular structures (drawing R. G. Scholtz; after Miroššayová 2018). 1 - Bajč; 2 - Čaka; 3 - Dvory nad Žitavou; 4 - Chotín; 5 - Šala; 6 - Vel'ký Cetín; 7 - Stránska; 8 - Budkovce; 9 - Michalovce (?); 10 - Bükkaranyos; 11 - Döge; 12 - Dunavecse; 13 - Ebes, Zsong-völgy; 14 - Ecser; 15 - Endrőd, site 19; 16 - Hajdúböszörmény, Juhász-tanya; 17 - Hajdúböszörmény; 18 - Hajdúnánás; 19 - Halmaj; 20 - Jászfelsőszentgyörgy, Túróczi-tanya; 21 - Ludas; Varjú-dúlő; 22 - Nagykálló, Industry Park; 23 - Nyírparasznya; 24 - Salgótarján, Industry Park II; 25 - Szikszó, Hell; 26 - Szolnok, Besenyszög; 27 - Szolnok, Papp-tanya; 28 - Szolnok, Zagyvapart (Alcsi); 29 - Tiszalök, Prison; 30 - Tiszapüspöki, Karancs-Háromág-dülő; 31 - Törökszentmiklós, Kenderpart; 32 - Vecsés, site 4; 33 - Vecsés, site 67 . 

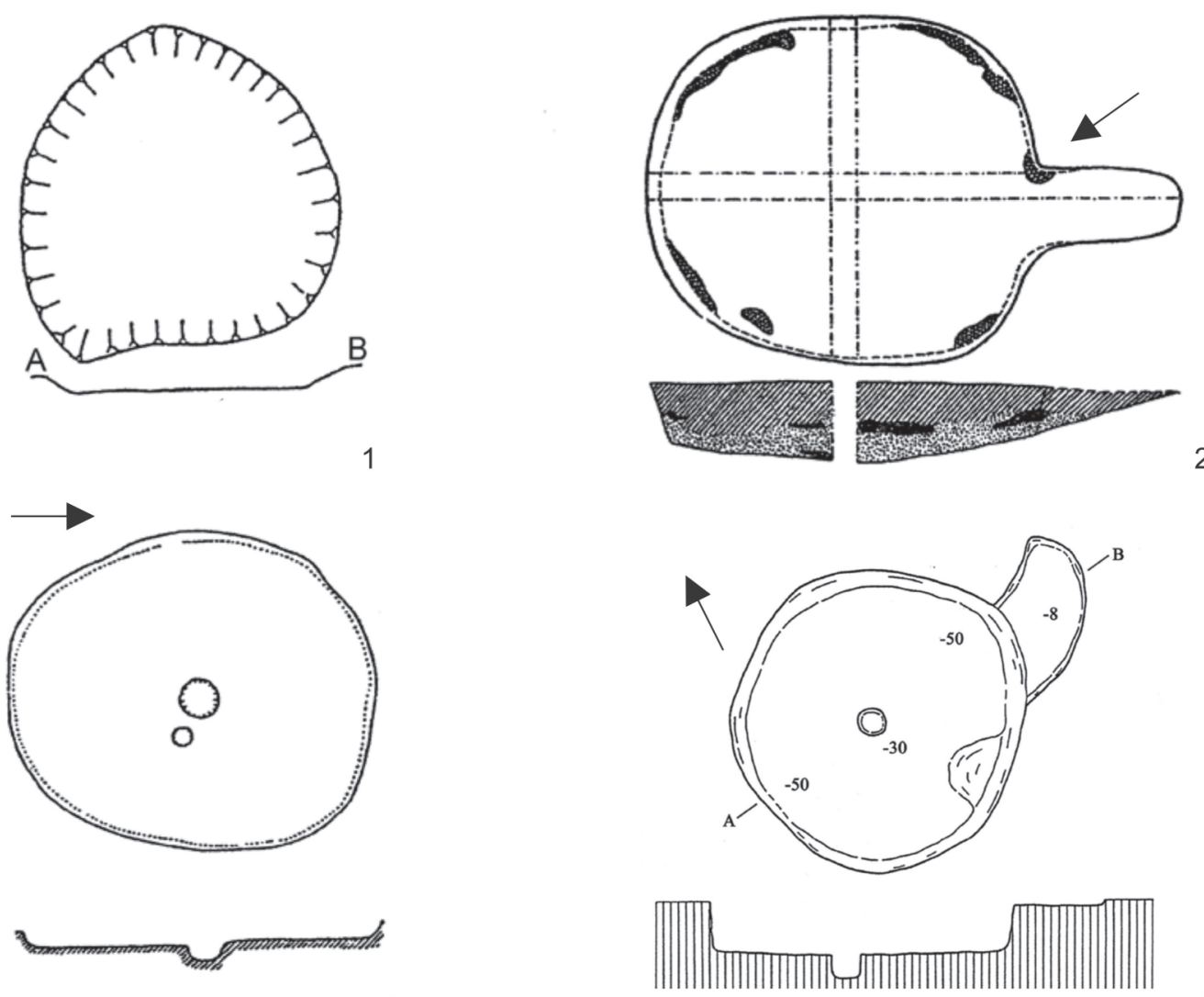

3
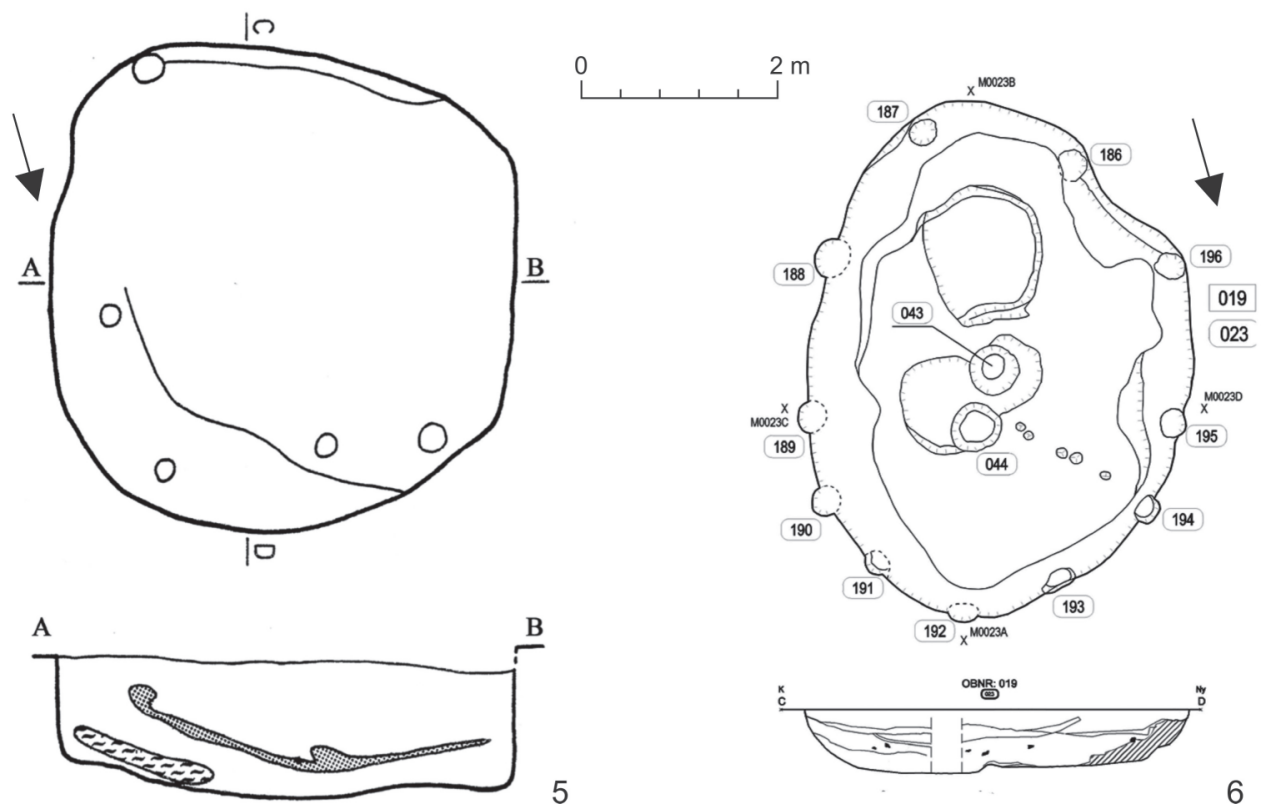

5

6

Pl. VI. Scythian Age sunken circular structures. 1, 2 - Type-A (Chotín and Dvory nad Žitavou; after Paulík 1957; Romsauer 1998); 3, 4 - Type-B (Bajč and Szolnok; after Cseh 1999; Točík 1964); 5, 6 - Type-C (Nitra and Nyírparasznya; after Czifra 2019; Romsauer 1993). 

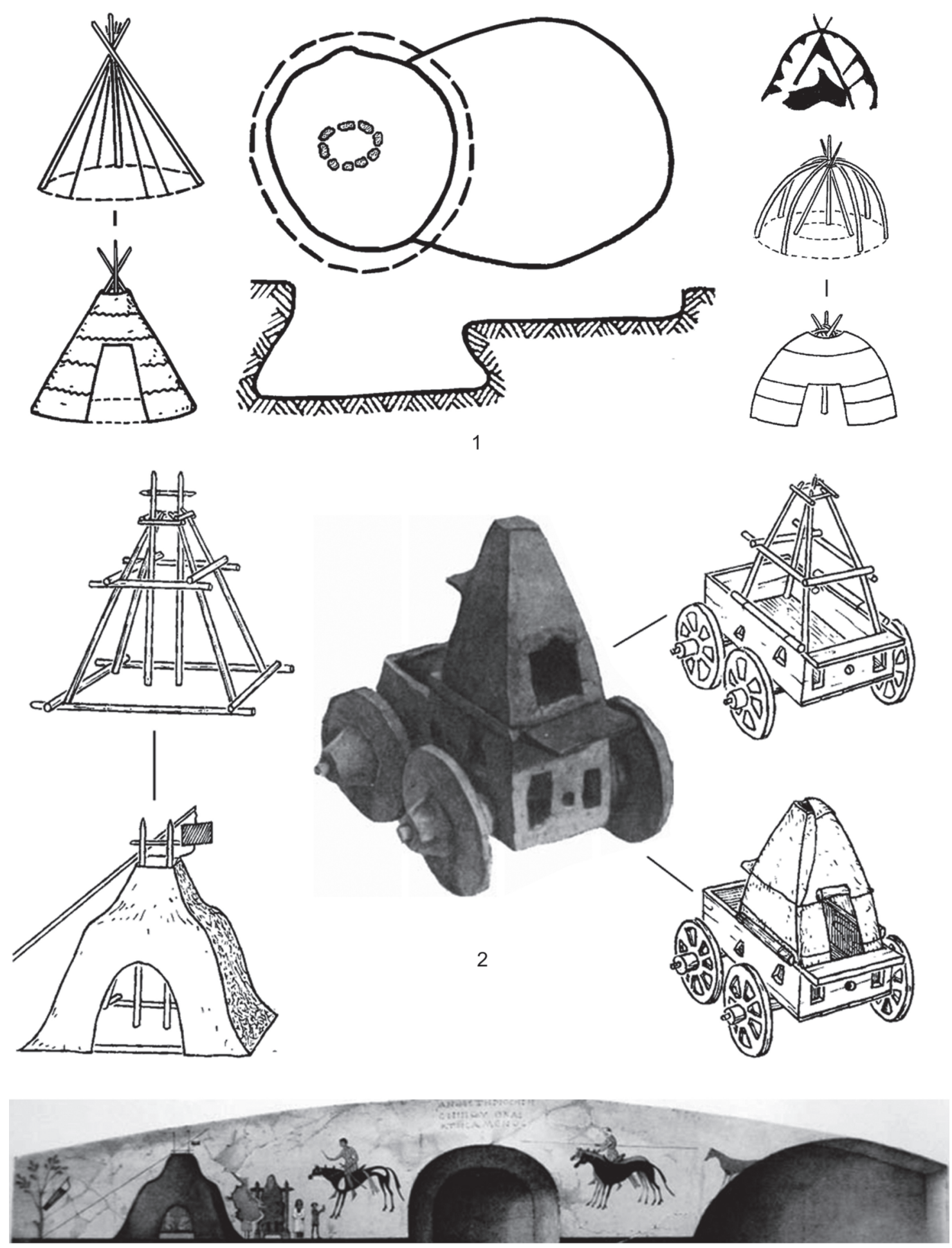


\section{REFERENCES}

Almássy 2001

Bottyán 1955

Cattani 1994

Chochorowski 1985

Csányi/Cseh/Tárnoki 1999

Cseh 1990

Cseh 1999

Cseh 2001

Cseh 2001a

Cseh 2006

Czifra 2006

Czifra 2016

Czifra 2019

Czifra/Kreiter/Pánczél 2015

Czifra et al. 2017

Dani 2004

Dani et al. 2006

Domboróczki 2004

Fodor 2011

Fodor 2013
K. Almássy: Együtt- vagy egymás mellett élés. Szkíta és kelta lelőhelyek Tiszavasvári környékén. A Nyíregyházi Jósa András Múzeum Évkönyve 43, 2001, 133 154.

Á. Bottyán: Szkiták a Magyar Alföldön. Régészeti Füzetek 1. Budapest 1955.

M.Cattani: Iron Age Dwellings in Endrőd 19 (SE Hungary). In: B. Genito (ed.): The Archaeology of the Steppes Mathods and Strategies. Napoli 1994, 209-219.

J. Chochorowski: Die Vekerzug-Kultur. Charakteristik der Funde. Prace Archeologiczné 36. Warsawa - Kraków 1985.

M. Csányi/J. Cseh/J. Tárnoki: Tiszapüspöki, Karancs, Háromág-dűlő: korabronzkori áldozati gödör és koravaskori épület. Archaeological Investigations in Hungary 1999, 2002, 47-62.

J. Cseh: Egy szkíta ház Szolnok - Zagyva-partról. A Scythian house from Szolnok-Zagyva-part. Múzeumi Levelek 63-64, 1990, 3-18.

J. Cseh: Szkíta telepobjektum alaprajzának és felépítményének rekonstrukciós lehetőségei (Szolnok-Zagyvapart). Ösrégészeti Levelek 1, 1999, 82, 83.

J. Cseh: Szkíta földmüvelők-állattartók településeinek régészeti nyomai a Zagyvamentén (Településtörténeti kutatások Szolnok határában 1986-1990 között). In: P. Havassy (ed.): Hatalmasok viadalokban. Az Alföld szkita kora/Sie sind in Kämpfen siegreich. Das Zeitalter der Skythen inder Tiefebene. Gyulai katalógusok 10. Gyula 2001, 79-95.

J. Cseh: Szkíta és kelta településnyomok Törökszentmiklós-Kenderparton. Ösrégészeti Levelek 3, 2001, 48-50.

J. Cseh: Archaeologia Scythica. Additamenta to History of the Middle Tisza Region in the Iron Age. Tisicum - A Jász-Nagykun-Szolnok Megyei Múzeumok Évkönyve 15, 2006, 13-41.

Sz. Czifra: Megjegyzések a szkítakori Alföld-csoport veremházainak kérdéséhez/Bemerkungen zur Frage der Grubenhäuser der skythenzeitlichen AlföldGruppe. Archaeológiai Értesítő 131, 2006, 169-178.

Sz. Czifra: Szkítakori település a Nyírségben: Nyírparasznya III. forduló (előzetes jelentés). A Scythian period settlement in the Nyírség region: Nyírparasznya, III. forduló (Preliminary report). Archaeological Investigations in Hungary 2011-2014, 2016, 99-119.

Sz. Czifra: Scythian age circular structures in the Carpathian Basin. In: M. Trefny (ed.): The Early Iron Age in Central Europe. Proceedings of the conference held on $2^{\text {nd }}-4^{\text {th }}$ of July 2015 in Hradec Králové, Czech Republic. Hradec Králové 2019, 248-266.

Sz. Czifra/A. Kreiter/P. Pánczél: Typology versus petrography: analysis of unique Scythian Age cups from Nyírparasznya (Hungary). In: I. Szatmári (ed.): An der Grenze der Bronze- und Eisenzeit. Festschrift für Tibor Kemenczei am 75. Geburtstag. Budapest 2015, 67-80.

Sz. Czifra/A. Kreiter/É. Kovács/Sz-M. Tóth/O. Viktorik/B. Tugya: Scythian Age settlement near Nagytarcsa. Acta Archaeologica Academiae Scientiarum Hungaricae 68, 2017, 241-298.

J. Dani: Ebes, Zsong-völgy. Archaeological Investigations in Hungary 2003, 2004, 205-208.

J. Dani/K. A. Szilágyi/M. Szelekovszky/Sz. Czifra/V. Kisjuhász: Előzetes jelentés a Berettyóújfalu, Nagy Bócs-dűlőlelőhelyen 2004-2005 során végzett megelőző feltárásról. Preliminary report of the excavations preceding investment at the Berettyóújfalu, Nagy Bócsdúlő site in 2004-2005. Archaeological Investigations in Hungary 2005, 2006, 5-32.

L. Domboróczki: Régészeti kutatások Ludas, Varjú-dűlőn 1998 és 2002 között (Előzetes jelentés). Archaeological investigations at Ludas, Varjú-dűlő between 1998 and 2002 (Preliminary report). Archaeological Investigations in Hungary 2002, 2004, 5-32.

I. Fodor: Szkíta temető Hajdúnánás határában (Előzetes jelentés). In: Á. Somogyvári/Gy. Székely (eds.): A Barbaricum ösvényein... A 2005-ben Kecskeméten tartott tudományos konferencia előadásai. Archaeologica Cumanica I. Kecskemét 2011, $11-26$.

I. Fodor: A Scythian Mirror from Hajdúnánás, Hungary. In: A. Anders/G. Kulcsár (eds.): Moments in time. Papers Presented to Pál Raczky on his $60^{\text {th }}$ Birthday. Budapest 2013, 831-838. 
Fodor 2015

Gyucha 2001

Hága/Németi 2015

Hellebrandt 2015

Hellmuth 2010

Herodotus

Istvánovits1997

Kashuba/Levitski 2012

Kemenczei 1994

Kemenczei 2001

Kemenczei 2009

Kozubová 2009

Kubarev/Ceveendorzh/Jacobson 2005

Lantos 2011

Lengyel 1960

Marchenko/Zhitnikov/Yakovenko 1988

Matuz 1997

Miroššayová 2018

Németi 1999

Nepper 1968

Nepper/Máté 1972

Párducz 1973

Patay/Kiss 2001-2002

Patay/Scholtz/Scard 2017
I. Fodor: Skythenzeitliche stabenden aus Bein von Hajdúnánás. In: I. Szatmári (Hrsg.): An der Grenze der Bronze- und Eisenzeit. Festchrift für Tibor Kemenczei zum 75. Geburtstag. Budapest 2015, 121-128.

A. Gyucha: A szkíta kor emlékei Békés megyében/The remains of the Scythian Age incounty Békés. In: P. Havassy (Hrsg.): Hatalmasok viadalokban. Az Alföld szkitakora/Sie sind in Kämpfen siegreich. Das Zeitalter der Skythen in der Tiefebene. Gyulai katalógusok 10. Gyula 2001, 115-128.

T. K. Hága/J. Németi: Vegyes rítus a vaskori temetkezésekben. Középső vaskor. In: T. K. Hága/O. Laczi/J. Dani (eds.): A Csillagos Ég Lakói. Fejezetek a temetkezésés a halottikultusz történetéböl Hajdú-Bihar megye területéról. Debrecen 2015, 49-54.

M. B. Hellebrandt: Die Häuser der Gáva-Kultur auf dem Fundort Köröm-Kápolna-domb (Ungarn). In: I. Szatmári (Hrsg.): An der Grenze der Bronze- und Eisenzeit. Festchrift für Tibor Kemenczei zum 75. Geburtstag. Budapest 2015, 199-212.

A. Hellmuth: Bogenschützen des Pontischen Raumes in der Älteren Eisenzeit. Typologische Gliederung, Verbreitung und Chronologie der skythischen Pfeilspitzen I-II. Universitätsforschungen zur Prähistorischen Archäologie 177. Bonn 2010.

The History of Herodotus: parallel English/Greek. English translation: G. C. Macaulay. London - New York 1890. https://sacred-texts.com/cla/hh/index.htm [08. 11. 2019].

E. Istvánovits: Nyíregyháza-Manda-bokor. Kora vaskori település a Kr.e. VI-IV. századból/Nyíregyháza-Manda-bokor. Early Iron Age settlement from the VIIV. B.C. In: P. Raczky/T. Kovács/A. Anders (eds.): Utak a múltba. Az M3-as autópálya régészeti leletmentései/Path into the past. Rescue excavation on the M3 motorway. Budapest 1997, 73-79, 181-182.

M. Kashuba/O. Levitski: The Hallstatt house-building techniques of the Carpathian-Danube region and the emergence of the circularpit-houses in the Early Scythian period in North-WestPontic. In: W. Blajer (red.): Peregrinationes archaeologicae in Asia et Europa Joanni Chochorowski dedicatae. Kraków 2012, 573-582. T. Kemenczei: Pfeilspitzen von Früh-Skythentyp aus Ostungarn (Korai szkíta típusú nyílhegyek Kelet-Magyarországon). Folia Archaeologica 43, 1994, 76-99.

T. Kemenczei: Szkíták az Alföldön. In: P. Havassy (Hrsg.): Hatalmasok viadalokban. Az Alföld szkita kora/Sie sind in Kämpfen siegreich. Das Zeitalter der Skythen in der Tiefebene. Gyulai katalógusok 10. Gyula 2001, 7-36.

T. Kemenczei: Studien zu den Denkmälern skythisch geprägter Alföld Gruppe. Inventaria Praehistorica Hungariae 12. Budapest 2009.

A. Kozubová: Dial'kové zbrane z pohrebísk vekerzugskej kultúry na juhozápadnom Slovensku (Fernwaffen aus Gräberfeldern der Vekerzug-Kultur in der Südwestslowakei). Zborník SNM 103. Archeológia 19, 2009, 65-130.

V. D. Kubarev/D. Ceveendorzh/E. Jacobson: Petroglifji Cagaai i Baga-Ojgura. Novosibirsk 2005.

A. Lantos: Szkíta kori telep Dunavecse határában. In: Á. Somogyvári/Gy. Székely (eds.): A Barbaricum ösvényein... A 2005-ben Kecskeméten tartott tudományos konferencia előadásai. Archaeologica Cumanica I.Kecskemét 2011, 27-48.

I. Lengyel: Tiszavasvári. Régészeti Füzetek 14, 1960, 20.

K. K. Marchenko/V. G. Zhitnikov/E. V. Yakovenko: Elizavetovskoe gorodishche-greko-varvarskoe torzhishche v del'te Dona/The Elizavetovskoe fortified settlement - a graeco-barbarian market place in the Don delta. Sovetskaya Arkheologiya 3, 1988, 63-78.

D. Matuz: Késő bronzkori és kora vaskori háztípusok és rekonstrukciós kísérleteik. Budapest Régiségei 31, 1997, 211-228.

E. Miroššayová: Sídliskové objekty Vekerzugskej kultúry v povodí Laborca. Východoslovenský pravek 18, 2018, 39-73.

I. Németi: Repertoriul arheological zonei Careiului. Bucureşti 1999.

M. I. Nepper: Szkítakori leletek a Déri Múzeumból. Scythian finds in the Déri Museum. Déri Múzeum Évkönyve 1966-1967, 1968 53-65.

M. I. Nepper/Sz. M. Máté: A Hajdú-Bihar megyei múzeumok régészeti tevékenysége 1969-1971 (Leletkataszter) Déri Múzeum Évkönyve 1971, 1972, 47.

M. Párducz: Probleme der Skythenzeit im Karpatenbecken. Acta Archaeologica Academiae Scientiarum Hungaricae 25, 1973, 29-73.

P. Patay/Z. Kiss: Az Alsótelekes-Dolinkai szkítakori temető közöletlen sírjai (az 1962.és 1964. évi feltárás eredményei). Folia Archaeologica 49-50, 2001-2002, 79-141.

R. Patay/R. G. Scholtz/A. Scard: Scythian Age quiver-mount from the outskirts of Gyömrő (Hungary). In: Sedem decénií Petra Romsauera. Studia Historia Nitrien- 
Paulík 1957

Raczky 2004

Rácz 2004

Rolle 1989

Romsauer 1991

Romsauer 1993

Romsauer 1998

Rusnák 2007

Scholtz 2007a

Scholtz 2007b

Scholtz 2008

Scholtz 2010a

Scholtz $2010 b$

Scholtz 2012

Sinica/Tel'nov 2014

Stronach 2004

Szabó 2004

Točík 1964

Tóth Farkas 2018

Vaday 2001

Vaday 2003

Vasiliev 1980

Veres 2003

Veres 2007 sia 2017. Supplementum - mimoriadne číslo časopisu venované životnému jubileu prof. Petra Romsauera. Nitra 2017, 469-480.

J. Paulík: Skýtsko-halštatská chata v Dvoroch nad Žitavou. Študijné zvesti Aú SAV 2, 1957, 75-81.

P. Raczky: Polgár Csőszhalom-dűlő. Archaeological Investigation in Hungary 2002, 2004, 257.

T. Rácz: Vecsés 67. számú lelöhely (Pest megye). Archaeological Investigation in Hungary 2002, 2004, 315.

R. Rolle: The World of the Scythians. Berkeley - Los Angeles 1989.

P. Romsauer: The earliest wheel-thrown pottery in the Carpathian Basin. Antiquity 65, 1991, 358-367.

P. Romsauer: Nové nálezy vekerzugskej skupiny z Nitry. Neuefunde der Vekerzug-Gruppe aus Nitra. Slovenská archeológia 41, 1993, 5-39.

P. Romsauer: Veränderungen in der Siedlungsstrukturen und in Besiedlung strategie während der erster Hälfte des 1 . Jahrtausends v. Ch. unter östlichen Einflüssen. In: C. Peretto/C. Giunchi (eds.): Actes du XIII Congrès 4. Forlì 1998, 629-635.

R. Rusnák: Objekty zo staršej a mladšej doby železnej zo Stránskej. Východoslovenský pravek $8,2007,59-75$.

R. Scholtz: Scythian Age finds on the M3 motorway in Szabalcs-Szatmár-Bereg County, Hungary. Východoslovenský pravek 8, 2007, 189-202.

R. Scholtz: Szkítakoritelepülés-éstemetőrészlet Tiszalökhatárában. Tiszalök, Börtön - Scythian Period settlement and cemetery fragment at Tiszalök (Tiszalök, prison). Archaeological Investigations in Hungary 2006, 2007, 53-65.

R. Scholtz: Szkíta, szarmata és késő népvándorláskori leletek Tiszavasvári-Kapusz-lapos lelőhelyről. Die skythischen, sarmatischen und Spätvölkerwanderungzeitliche Funde von Tiszavasvári-Kapusz-lapos. A Nyíregyházi Jósa András Múzeum Évkönyve 50, 2008, 225-269.

R. Scholtz: New data on the Scythian Age settlement history in Szabolcs County, Hungary. In: S. Bereczki (ed.): Iron Age Communities in the Carpathian Basin. Proceedings of the International Colloquium from Târgu Mureş, 9-11 October 2009. Târgu Mureş 2010, 79-98.

R. Scholtz: Szkíták nyomában Magyarországon. In: "Magyarország és Azerbajdzsán: A Kultúrák párbeszéde". IV. Nemzetközi tudományos konferencia. 2009. November 17-19. Budapest 2010, 379-398.

R. Scholtz: Scythian Age Burials at Tiszalök. In: S. Bereczki (ed.): Iron Age Rites and Ritual in the Carpathian Basin. Proceedings of the International Colloquium from Târgu Mures, 7-9 October 2011. Târgu Mureş 2012, 77-100.

V. S. Sinica/N. P. Tel'nov: Scythian dwellings in IV-II centuries BC in the North Black Sea Littoral. Archeologiia i davnaia istoriia Ukrajini 2014, 18-36.

D. Stronach: On the Antiquity of the Yurt: Evidence from Arjan and Elsewhere. The Silk road Fundation newsletter 2004/2. http://www.silkroadfoundation.org newsletter/2004vol2num1/yurt.htm [08. 11. 2019].

V. G. Szabó: Ház, település és településszerkezet a későbronzkori (BD, HA, Hperiódus) Tiszavidéken. In: E. Gy. Nagy/J. Dani/Zs. Hajdú (eds.): $M \Omega M O \Sigma I I$. Őskoros Kutatók II. Összejövetelének konferenciakötete. Debrecen 2004, 137170.

A. Točík: Záchranný výskum v Bajč-Vlkanove v rokoch 1959-1960. Študijné zvesti Aú SAV 12, 1964, 5-185.

M. Tóth Farkas: Szkíta kori nyílhegyek a Budapesti Történeti Múzeum gyüjteményében. In: Cs. Balogh/B. Major/A. Türk (Szerk.): Relationesrerum. Régészeti tanulmányok Nagy Margit tiszteletére. Budapest 2018, 99-113.

A. Vaday: Előzetes jelentés a Salgótarján, Iparipark II. régészeti feltárásáról. Nógrád Megyei Múzeumok Évkönyve 25, 2001, 209-215.

A. Vaday: Salgótarján, Ipari-park II. Lelőhely. Salgótarján, Industrial Park II site. Archaeological Investigations in Hungary 2000, 2001, 31-38.

V. Vasiliev: Sciţii agatîrşi pe teritoriul României. Cluj-Napoca 1980.

J. Veres: Szkíta kori település Polgár határában. Ósrégészeti Levelek 5, 2003, 83-93.

J. Veres: Adatok Északkelet-Magyarország szkíta korához. Kisgyőr-Bubtető szkíta kori temető közöletlen anyagának feldolgozása. Herman Ottó Múzeum Évkönyve 46, 2007, 39-86. 


\title{
Zahíbená kruhová stavba zo skýtskeho obdobia v okolí Hajdúböszörmény (Mad’arsko)
}

\author{
Marianna Bálint - Alexandra Scard - Robert G. Scholtz
}

\begin{abstract}
Súhrn
Múzeum Hájdúsági v Hajdúböszörmény uskutočnilo v lete 2017 výskum, ktorý určil presný rozsah a stav archeologickej lokality Hajdúböszörmény, Juhász-szállás, tiež známej ako Partos-csárda (obr. 1). Počas výskumu bolo na ploche s rozlohou $660 \mathrm{~m}^{2}$ odkrytých 12 archeologických objektov - osem úlovitých jám, dve kolové jamy, dom a jedna priekopa (tab. I: 2, 3). V dôsledku nedostatku datovatel'ných predmetov môžu byt’ do strednej doby železnej s istotou datované len tri objekty - č. 6-8: kruhová stavba a dve kolové jamy. Primárnym cielom tohto článku je predstavit tieto novoobjavené sídliskové objekty zo skýtskeho obdobia vekerzugskej kultúry (tab. I: 2). Napriek fragmentárnosti poskytli nálezy dôležité údaje pre presnejšie pochopenie osídlenia strednej doby železnej a histórie stavby domov v skúmanom regióne.

Kruhová sídlisková stavba s charakteristickým konštrukčným prvkom - centrálnym stĺpom -je výrazným príkladom pozostatkov predskýteho-skýtskeho domu (8.-3. stor. pred n. 1.). Tento jurtovitý variant (tab. II; VII) možno pozorovat’ v celom teritóriu vekerzugskej kultúry (tab. V). Určenie veku a funkcie týchto sídliskových objektov je problematické. Podla trojhranného bronzového hrotu šípu a charakteristického keramického materiálu, ako aj podobných kruhových stavieb (napr. Törökszentmiklós, Kenderpart, obj. 22; Cseh 2001, obr. 2) je možné lokalitu Hajdúböszörmény datovat̉ do 6.-5. stor. pred n. 1., teda do zlatého veku vekerzugskej kultúry. Ked’že ani jeden z odkrytých objektov neobsahoval materiál keltského pôvodu, je pravdepodobné, že obyvatelia osady sa s pristahovalectvom Keltov nestretli.

Na základe analyzovaných dát rozlišujú autori tri hlavné typy: bez kolových jám (typ A; tab. VI: 1, 2), s jednou kolovou jamou uprostred (typ B; tab. VI: 3, 4) a s viacerými kolovými jamami (typ C; tab. VI: 5, 6; tabela 1). V Karpatskej kotline sa zahíbené kruhové stavby po prvýkrát objavili na sídliskách neskorej doby bronzovej-v kultúre popolnicových polí, gávskej a kyjatickej kultúre, a na sídliskách staršej doby železnej - v basarabskej a mezőcsátskej kultúre (fázy HA-HC).

Mad’arskí bádatelia vo všeobecnosti interpretovali tieto stavby ako pomocné stavby: jurtovité domy, koliby, dielne, hospodárske stavby, zásobné alebo pracovné jamy (Domboróczki 2004; Hellebrandt 2015; Kemenczei 2009; Lantos 2011, Szabó 2004; Vaday 2003), zatial' čo východoeurópski archeológovia interpretujú podobné kruhové stavby ako domy (Kashuba/Levitski 2012).

Možno dúfat, že časom bližšie pochopíme presnú chronológiu týchto stavieb a sídlisk vd’aka výsledkom výskumov, ktoré budú v blízkej budúcnosti pokračovat'.
\end{abstract}

Obr. 1. Hajdúböszörmény v Mad’arsku.

Tabela 1. Zahĺbené kruhové stavby zo skýtskeho obdobia v Mad’arsku.

Tab. I. Hajdúböszörmény, Juhász-szállás, zemepisná poloha v rámci druhého vojenského mapovania (1853) a komplexná mapa výskumu.

Tab. II. Hajdúböszörmény, Juhász-szállás, 1-3-objekt 6; 4 - objekt 7.

Tab. III. Vybrané archeologické nálezy z objektu 6 . V ruke vyrábaná keramika.

Tab. IV. Vybrané archeologické nálezy z objektu 6. 1-6, 8, 10 - na kruhu vytáčaná keramika; 7 - hlinený praslen; 9 bronzový hrot šípu.

Tab. V. Mapa lokalít so zahĺbenými kruhovými stavbami zo skýtskeho obdobia (kresba R. G. Scholtz, podla Miroššayová 2018). 1 - Bajč; 2 - Čaka; 3 - Dvory nad Žitavou; 4 - Chotín; 5 - Šal'a; 6 - Vel'ký Cetín; 7 - Stránska; 8 - Budkovce; 9 - Michalovce (?); 10 - Bükkaranyos; 11 - Döge; 12 - Dunavecse; 13 - Ebes, Zsong-völgy; 14 - Ecser; 15 - Endrőd, nálezisko 19; 16 - Hajdúböszörmény, Juhász-tanya; 17 - Hajdúböszörmény; 18 - Hajdúnánás; 19 - Halmaj; 20 Jászfelsőszentgyörgy, Túróczi-tanya; 21 - Ludas; Varjú-dűlő; 22 - Nagykálló, priemyselný park; 23 - Nyírparasznya; 24 - Salgótarján, priemyselný park II; 25 - Szikszó, Hell; 26 - Szolnok, Besenyszög; 27 - Szolnok, Papp-tanya; 28 Szolnok, Zagyvapart (Alcsi); 29 - Tiszalök, väzenie; 30 - Tiszapüspöki, Karancs-Háromág-dűlő; 31 - Törökszentmiklós, Kenderpart; 32 - Vecsés, nálezisko 4; 33 - Vecsés, nálezisko 67. 
Tab. VI. Zahíbené kruhové stavby zo skýtskeho obdobia. 1, 2 - typ A (Chotín a Dvory nad Žitavou; podla Paulík 1957; Romsauer 1998); 3, 4 - typ B (Bajč a Szolnok; podla Cseh 1999; Točík 1964); 5, 6 - typ C (Nitra a Nyírparasznya; podl’a Czifra 2019; Romsauer 1993).

Tab. VII. Rekonštrukcie skýtskych a sarmatských júrt a jurtovitých stavieb. 1 - Lisaja Gora; 2 - Krym; 3 - Pantikapea (podla Sinica/Telnov 2014).

Preložila Viera Tejbusová

Dr. Marianna Bálint

Hajdúsági Museum

1 Kossuth Lajos str.

H - 4220 Hajdúböszörmény

regesz@hajdusagimuzeum.hu

Robert G. Scholtz

13 Gábor Áron str.

H - 4033 Debrecen

scholtzrobert@gmail.com

\author{
Alexandra Scard \\ 102 Chiltern Close \\ Warmley \\ UK - BS30 8UN Bristol \\ alexandra.n.90@hotmail.co.uk
}

